Environnement Urbain

Urban Environment

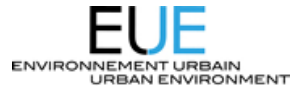

\title{
What urban government for a sustainable urban planning? Conceptual analysis based on the case study of Tunisian cities and their local Agenda 21
}

\section{Hatem Kahloun}

Volume 4, 2010

URI : https://id.erudit.org/iderudit/1005644ar

DOI : https://doi.org/10.7202/1005644ar

Aller au sommaire du numéro

\section{Éditeur(s)}

Réseau Villes Régions Monde

ISSN

1916-4645 (numérique)

Découvrir la revue

Citer cet article

Kahloun, H. (2010). What urban government for a sustainable urban planning? Conceptual analysis based on the case study of Tunisian cities and their local Agenda 21. Environnement Urbain / Urban Environment, 4, c31-c42. https://doi.org/10.7202/1005644ar

\section{Résumé de l'article}

A Tunis, comme dans la majorité des villes en développement, le système de pouvoir centralisé se présente comme l'unique pourvoyeur-régulateur de l'urbanisation et de sa durabilité. Dans de pareils contextes qui sous-intègrent la participation citoyenne dans la gestion des villes, des notions telles que " gouvernement urbain " et " gouvernance " peuvent apparaître tout particulièrement inappropriées face aux fonctionnements en " réseaux » des acteurs dans leurs structures sociales et politiques. L'étude des villes tunisiennes révèle l'émergence de nouvelles formes de gouvernement local dont les actions et les décisions demeurent fortement fragilisées par les pouvoirs extra-locaux. Ce paradoxe dans les formes de pouvoirs et dans leur manière d'agir amènent à s'interroger, pour ainsi partir d'une confrontation entre contextes et " concepts », sur les enjeux de la démocratisation de l'action locale et leurs répercussions sur l'urbanisme durable.
Tous droits réservés @ Réseau Villes Régions Monde,

Ce document est protégé par la loi sur le droit d'auteur. L’utilisation des services d'Érudit (y compris la reproduction) est assujettie à sa politique d'utilisation que vous pouvez consulter en ligne.

https://apropos.erudit.org/fr/usagers/politique-dutilisation/ 


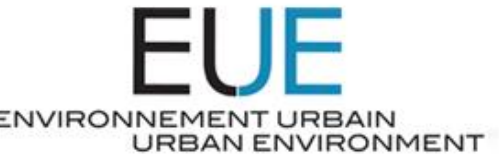

\title{
WHAT URBAN GOVERNMENT FOR A SUSTAINABLE URBAN PLANNING? CONCEPTUAL ANALYSIS BASED ON THE CASE STUDY OF TUNISIAN CITIES AND THEIR LOCAL AGENDA 2 I
}

\author{
Hatem KAHLOUN
}

\begin{abstract}
I RÉSUMÉ
A Tunis, comme dans la majorité des villes en développement, le système de pouvoir centralisé se présente comme l'unique pourvoyeur-régulateur de l'urbanisation et de sa durabilité. Dans de pareils contextes qui sous-intègrent la participation citoyenne dans la gestion des villes, des notions telles que " gouvernement urbain » et " gouvernance » peuvent apparaître tout particulièrement inappropriées face aux fonctionnements en « réseaux » des acteurs dans leurs structures sociales et politiques. L'étude des villes tunisiennes révèle l'émergence de nouvelles formes de gouvernement local dont les actions et les décisions demeurent fortement fragilisées par les pouvoirs extra-locaux. Ce paradoxe dans les formes de pouvoirs et dans leur manière d'agir amènent à s'interroger, pour ainsi partir d'une confrontation entre contextes et " concepts ", sur les enjeux de la démocratisation de l'action locale et leurs répercussions sur l'urbanisme durable.
\end{abstract}

MOTS-CLÉS - Sustainable urban planning, local agenda, urban government, governance, practices of complicity

\begin{abstract}
- ABSTRACT
In Tunis, as in most developing cities, the highly centralized system of authority can be seen as the single supplier-regulator of urban development and sustainability. In such contexts in which citizen participation in urban management is undervalued, concepts such as "urban government" and "governance" may appear to be particularly irrelevant to the "networking" practices of actors within their own social and political structures. With a focus on the system of local power in Tunisian cities, this study shows that actions and decisions taken by emerging forms of local government remain highly vulnerable due to extra-local forces. Such a paradox in the forms of power and their manner of conduct, by comparing contextual and conceptual frameworks, draws attention to the issues of democracy in action at the local level and the overall impact of these issues on sustainable urban planning.
\end{abstract}

KEYWORDS - Urbanisme durable, plan d'action local, gouvernement urbain, gouvernance, pratiques de connivence

I Author's coordinates: Hatem Kahloun, Department of urban planning, ISTEUB, Carthage University, Tunis. Mail : Institut Supérieur des Technologies de l'Environnement, de l'Urbanisme et du Bâtiment, e-mail: hatem.kahloun@laposte.net 


\section{INTRODUCTION}

The debate on sustainable cities seems to be one of the major political challenges facing the modern state. Urban governments are seeking ways to reduce the unjustifiably high levels of energy and land consumption and preserve and protect the housing stock. In North African cities, the underlying causes of this resource crisis are the low density of the existing urban fabric, the lack of control of urban sprawl, and the increasing intensity of agricultural land conversion which contributes to the rapid proliferation of informal settlements. The apparent absence of rationality in urban planning often results from the absence of functional procedures and institutional arrangements that would be necessary to establish and oversee the application of sustainable construction standards. Moreover, zoning measures motivated by opportunistic considerations which do not conserve resources in the provision of activities, result not only from the growth and the diversification of transport systems and mobility patterns, but also by the physical separation and distance between residential and workplace locations. Finally, the crisis stems from a failure to provide extensive road networks and increase access and speed to centres and transit nodes while supporting heavier vehicular loads.

Clearly, the chances of sustainable urban planning becoming reality in a context of deregulation characterized by the inadequacy of regulatory mechanisms (Boyer and Saillard, 2002) and urban management tools are remote. This paper points to some of the factors and practices that have given rise to this crisis. Given the apparent dichotomy between government and private sector interests, our aim is to provide guidance in determining which public initiatives should be taken at the various decisionmaking stages and to examine the role of authorities in the production of sustainable cities. This leads us to consider both the legitimate and illegitimate functions of urban governmental organisations, and their part in the definition of urban policies prescribed by the central government. Taking into account the role of local authorities in decision-making processes throws a different light on the assumptions about urban sustainability. We can restrict the study of the domain in which local and central governments operate to the existence or lack of power vested to local bodies by the state. To provide a better theoretical grounding, the interplay between structures and actors in informal networks must be addressed. Local government authorities operating in both formal and informal "non-systemic networks" present within or outside social, political and territorial urban systems could be the key to achieving the implementation of sustainable urban planning. Furthermore, the analysis of the case of Tunisian urban governments and their local planning agendas to implement sustainable urban planning allows us to show that a commitment to "sustainable projects" contributes towards the increase of democratization. For instance, local authorities could move outside the regulatory frameworks and take on new informal forms (Stone, 1989) based on complicity and on participating in informal networks and coalitions recognized by both external and local actors.

\section{OVERVIEW OF RESEARCH, FIELDWORK INSTRUMENTS AND METHODS OF ANALYSIS}

To provide insights into these issues, a descriptive-transverse study was conducted using a case study approach to collect detailed data on the various forms of urban government and local authorities across Tunisian cities. The scientific method consisted of thirty semi-structured interviews and an analysis of archived records relating to the composition and operations of the two terms of the elected municipal councils during the period 19952005 within ten cities located on the outskirts of Tunis.

The records provided a host of information on council members, including age, place of birth, occupation, political affiliation, number of years serving on council and political stand. To verify whether they are representative of the population, electoral lists were processed and analysed according to profession. Categories of voters were defined based on their occupation, level of education as well as spatial distribution across neighbourhoods. Qualitative interview data was analysed in order to validate these results by conducting tests until saturation was reached. Drawing on a wide range of information, different categories of actors were defined and composed of local elected members, officials and municipal technicians and well-to-do leaders involved in the decision-making processes, including neighbourhood committee members and former members of municipal councils.

Based on the transcribed discourses, a content analysis was performed to identify categories and conceptual developments. Research initially focused on an interpretation of word frequency and the repeated occurrence of expressions. Conceptual references 
used in the reports were then compared. By applying this analytical approach, we were confronted with some methodological constraints. Indeed, for the material and its interpretation phase, we tried to move away from the issues surrounding political discourse and its implications to seek explanations at different scales of decision-making. This more objective approach allowed us to better reflect the importance of the interface between actors and specific urban development actions without detaching them from existing power structures and network-based forms of organizing.

\section{WHAT TYPE OF DEMOCRATIC GOVERNMENT CAN MAKE CITIES MORE SUSTAINABLE? DEFINING SITUATIONAL CONCEPTS}

In game theory, it is assumed that public decisions, actions and strategies are built on existing democratic structures which are strengthened by a range of interventions at different scales, particularly when sustainability is involved (Gibbs and Jonas, 2000). Indeed, an urban government must bring together a host of agents and social actors to help ground systemic decision-making. Although local authorities do not act in a transparent manner, the objectives of sustainability seem to be effectively met through the democratization of local governments in North African cities. While policymakers make extensive use of concepts such as "sustainable planning", "urban government" and "governance", we will place them into context and draw comparisons between territorial scales and constructs.

The expressions "sustainable city" and "sustainable planning" refer, by extension, to a new way of thinking based on the territory to develop cities. This conceptual model of planning, promoted by United Nations agencies and established through international programmes has evolved gradually in the past 20 years in the United states at a time when cities were faced with the challenges of metropolitan growth characterised by urban and spatial sprawl accelerated by such phenomenon as ex-urbanization and suburbanisation. New requirements for sustainability were introduced to design urban policies that address the issues of uncontrolled and at times extreme and costly sprawl in outlying areas. Populations living in these areas must often rely primarily on the passenger automobile for their mobility, which increases natural resource and energy consumption. On a more theoretical level, sustainable urban development is seen as a move towards a more progressive vision of the city committed to the application of urban ecology principles. Pilot projects have shown the benefits and demonstrated their feasibility. A participatory approach is critical to achieving sustainable urban planning. However, this approach comes into conflict with local authorities and their relative autonomy to implement policies in their jurisdictions. How can the key underlying dimensions for understanding the distribution of power at the urban level be correctly identified when the state continues to play such a preeminent role?

The urban regime theory (Stone, 1993) defines power as the set of arrangements and relationships, both formal and informal. This theory goes beyond the division of roles between public and private sectors; instead, it argues that actors cooperate and have pooled resources to formulate and implement government decisions. In fact, according to Stone, quoted by Le Galès (2003), such political arrangements shaped urban regimes that resulted in setting up a policy-action matrix. It follows that urban governments play a determining role in sustainable development policy formulation and implementation. In constructing his urban regime paradigm, Stone focuses on the capacity building process to enable governments to provide coordination between various actors and to carry-out sustainable policies in a fragmented urban context. In this case, we would argue that the urban regime is a useful framework for understanding sustainable urban planning. Indeed, on a local scale, urban regime can be helpful "to analyse the characteristics of local governing coalitions and their policies" (Gibbs and Jonas, 2000, p.309). Moreover, by adopting a pluralistic and progressive outlook, urban regime theory suggests that the role of government may be limited to one of arbitrator between competing and pre-existing interests and preferences. Under such dynamic and constantly evolving conditions, coalitions are understood as the moment of creating and channelling shared preferences. Commenting on the Stone analysis, Godard argues that: "the legitimacy of the election in an urban political system is not sufficient to establish the local power. To govern, this power must succeed in mobilizing sustainable coalitions of interest around the determination of priorities" (Godard, 1997, p. 132). Indeed, until now, the idea of coalition has gained considerable support in the definition and validation of political structures and the function of power.

In short, the research carried out so far on networks and coalitions is still preliminary and there is no well-founded theory to date. This fact has been well established and documented in the various publications of Lemieux (1976, 1977, 1991, 1997) and 
in the work of Degenne and Forsé (1994). These authors offer insights on the possible limits of theorizations and conceptualizations on networks in comparison with the game or the systems approach theories. Through his research on networks, systems and empowerment, Lemieux has found that coalitions can be described as a form of network. Drawing on the field of alliances, Lemieux offers the following definition of the coalition as "individual or collective actors working together on a temporary basis who offer support as well as come into conflict in their results and relationships. They can capture more power and therefore prevail over their opponents and secure more advantages than could be obtained if they did not join the coalition" (Lemieux, 1997, p. 367).

Indeed, in his theory on the networks and social systems linkages, Lemieux considers that networks, by comparing them to systems,

\begin{abstract}
"[C]ould be characterised as intra-systemic (for example, informal groups within organization), inter-systemic (for example, [...] alliance networks between states), transsystemic (for example, a network [... that] crosses somehow industrial or territorial systems), and para-systemic (for example [a network] as a temporary step in the establishment of a system)." (Lemieux, 1976, p. 257)
\end{abstract}

Yet, a network is never systemic and cannot be subject to formalization. "With a lower degree of organization, networks must be considered separate from systems" (Lemieux, 1976, p. 257). Viewed in this light, it can be argued that governance is an expression of the process by which people meet in order to,

"[C]reate from the very beginning a shared universe and commit efforts to mobilize the required resources. Governance can be conceived more as a series of informal arrangements between actors within the same private and public domains, and is less about occupying institutional positions. These arrangements are built around agreements on the principles of legitimacy". (Gaudin, Novarina, 1997, p. 63).

Despite their conceptual limitations, network and urban regime theories have highlighted the importance of networking and partnership processes. However, the failure to properly consider stakeholder interactions at spatial scales is a major cause of uncertainty (Gibbs and Jonas, 2000).
What the innovative notion of governance offers coalition, urban regime and urban government "theories" cannot be summarized simply as the experience of power swapping between the state and local governments. Furthermore, it is not a reflection of the attempt to coordinate public action by building vertical and horizontal relationships through coalitions and networking. In the context of developing countries, this particular type of governance does bring the expected additional benefits to the new modes of urban regulation (De Terssac, 2003). Rather, governance provides the framework in which local actors benefit from empowerment and redefine their relationships in a political context marked by the fracture and the diversity of coalitions involving statesociety and state-cities institutions mandated to promote and oversee public-private partnerships (PPP). Moreover, governance is a reflection of new formal and informal arrangements operating through networks that offer opportunities to improve the democratic dialogue among actors at the local level engaged in social and political negotiations. If governance is considered by urban governments as an innovative concept, that is because it tries to reconstruct the mechanisms underlying policy-making through political and social regulations. It is in this sense that some authors describe governance as a model of change based on a strong political will to implement sustainable planning and to draw attention to project methods or design as well as processes rather than focusing solely on results. With this mind, Souami (1998) argues that the development of the concept of governance reveals a crisis of the welfare state and brings into focus the key issues surrounding decentralization. According to the author, governance stems from an ideology of fear of conflict and of anxiety about the capacities and the powers of the state. The fall of urban governments and the rise of urban governance are expressions of the collective failure of actors falling outside the state's sphere of influence "which has adopted a neo-liberal economic agenda, which includes the new model of threat" (Souami, 1998, p. 163). According to Le Galès, the concept of governance does not warrant the development of a theory. This seems to be an interesting line of research to pursue. Instead, the concept of governance helps to understand contemporary forms of government and state-based processes. In the author's view, governance is a second-order concept that, while not able to provide answers, is useful in formulating questions (Le Galès, 2003). 
It follows that local governments are incapable of forming an urban regime. Arrangements between public and private sector interests strengthen the role of the regional authority while providing a response to the state policy on regional land use planning. In addition, elements of the theory of urban government, i.e. the existence of actors, the ability to act and the presence of organized interests, cannot be considered within the scope of a regional authority which exercises hegemony and of cities without an "ability to act" (Gibbs and Jonas, 2000). Le Galès (1998) and Gibbs and Jonas (2000) critically assess the limits of importing notions of coalitions, urban regime theory and governance from the American and the European experience to the sharply contrasting context in Tunisia marked by a strong central state and its presence at different territorial levels. Indeed, if these theories require cooperation and relatively stable arrangements between political interests, bringing together stakeholders and other public and private actors, this context cannot be analysed from the standpoint of governance. The scarcity of private enterprise in Tunisian cities means they have no impact on urbanization since they display no systematic dependency.

The concentration of economic, administrative and political power in Tunis increases the propensity of actors to form local coalitions in close cooperation with regional authorities directly answerable to the state. The local power base must yield to regional directives in carrying-out national policies or in applying sustainable development principles. Involved in the national and regional decision-making processes, local policies are able to conduct sustainable planning initiatives.

Can the concept of governance be applied to the urban context of Tunisian cities? The answer is yes, but government must be understood in the medieval sense of the term, that is the locus of power and management. Local power in the cities can rather be studied in terms of "governmentality". According to Gaudin, such an idea "had been developed by the philosopher Michel Foucault at the end of his life and it dealt with political practices in relation to protective paternal authority" (Gaudin, 2002, p. 33). In Tunisia, local authorities are not involved in the process of urbanization and governance is virtually absent from cities because of the inadequacy and fragility of the local political system. On the one hand, technical and financial resources need to be mobilized and on the other, often unstable coalitions need training and institutional support. The hegemonic state is responsible for the present situation. However, the proximity to Tunis and the centre of power allows local communities and settlements to exercise power and control over their territories. In fact, these edge cities must accept the burden of implementing modern urban planning schemes, which means in practice, to agree to take charge of promoting Information and communication technology's (ICT).

The method used for evaluating the scope and effectiveness of these concepts was to study government representative structures in Tunisian cities and more particularly in the small town of Medjez El Bab where "local power" was exercised by actors in the attempt to apply the various principles involved in sustainable urban planning. Weak power structures at the local level and conflicts of interest between actors have fuelled the emergence of coalitions and complicit actions in the deliver of services to meet local demand and the development of urban projects.

\section{LONG DELAYS IN THE DEMOCRATIZATION OF LOCAL GOVERNMENTS}

Between 1985 and 1989, during the recentralization reform, Tunisian local political systems were dramatically altered to better reflect the policy of assigning more power to regional delegates. The hierarchical structure was modified to provide governors and the regional power base with more control at the expense of local elected officials. Within this new territorial arrangement, governors assumed greater power and were appointed the task of implementing the state policy aimed at reducing regional disparities while leaving aside urban policy programmes "targeting" priority territories. Faced with an ineffective local power base and given the predominance of state regulations and the control granted to regional governors, how can we describe the political arrangements found in cities today?

In Tunisian cities, municipal council is the most institutionalized structure of political power in the local government system. Even so, examining the municipal council structure provides little information about the role of local power in the social composition of cities. This political arrangement, which is established by the central government, devotes little attention to socio-cultural diversity and to the interests of the local actors and agencies. This insufficient representation may limit the ability to meet the aspirations of the population and give precedence to some socio-professional categories (SPC) in decision-making processes over others. Under this political arrangement, urban governments have little 
choice but to favour some categories while other voices often remain unheard within the political system made up of community leaders. An analysis of councils confirms in part the extent to which this representational bias is supported by the current structure.

Dominated by the ruling party coordination committees, the local political system is subject to the lists of electoral candidates proposed by its subcommittees and cells. In the smaller territorial subdivisions, the pre-existing lists, the absence of political opposition, constituent mobilization and the leverage of elected representatives from the single ruling party, all combine to ensure that the government can continue to oversee the population. Moreover, through its local cells, the ruling party can tighten its control over regional and local space. Cities, regardless of their size, do not develop independent political institutions mandated to make decisions. The centralization of political and decisionmaking power in the capital locks cities and their surrounding suburbs and rural areas into a national policy framework. The monopoly exercised by central political authorities through coordinating committees and neighbourhoods cells in the urban areas, and village councils in the rural areas is a reflection of the hostility towards political pluralism in the way in which power is shared and represented within cities.

Some SPCs are excluded from local representation in official political structures because of a system that promotes the interests of elite at the expense of a more diverse social base composed mainly of the working-class. Since the electorate is dominated by non elite groups, SPCs that have no real representation are needed to hold legitimate elections. Their presence, strongly desired in the electoral register, does eventually make representation in municipal councils more equitable. This political stake granted to local special interests and minority groups who can take part in the local power structure carries clearly more weight than other selection criteria such as the availability of elected representatives to serve the public interest, building capacity for resource mobilization, the mayor's personality and the social and professional diversity of council members. In sum, the state holds a monopoly on the selection of local representatives, which seems to be the only way agglomerations, towns, or neighbourhoods are able to exert political influence.

Clearly, the broad geographical basis in which the dominant party operates, and its high level of social acceptability hinder the emergence of political pluralism at the local level. Pluralism is undermined by the absence of financial support or targeted initiatives and programmes. Slightly less than $5 \%$ of elected members of council only, came from the middle to lower classes and formed the opposition (personal survey, 2005). These elected officials have recently joined the council and with hardly any clout, are often absent from meetings. In most small or medium sized cities, the average council member turnover rate is never more than 50\%. Mayors and councillors are charged with multiple mandates and thus can explain the reasons why the democratisation of local decisionmaking mechanisms has so far been disappointing.

The central state exercises its administrative and political power across various jurisdictional levels. However, in urban areas, the legitimacy of such actions can be established outside state structures. Moreover, powers granted to municipal councils in the area of urban planning are incomplete to the extent that the transfer of legitimacy does not involve urban policy instruments. Nevertheless, elected members and managers develop the necessary skills to develop local initiatives instead of the ones proposed and find ways around the official channels. This enables them to decrease the risk of triggering social and urban tensions around speculation and land ownership claims.

The inherent inefficiency of the local political system comes from the fact that regulation mechanisms are highly centralized. The state defines the broad rules and possesses significant resources to sustain its role as a regulator at the expense of a democratic local government. It can therefore exert "hierarchical control" by its virtual monopoly over the distribution of resources. An indication of the weakness of local power is found in the central authority's control over coalitions, conflicts and the coordination of the local economic interests. Indeed, as Le Galès indicates, this type of policy "involves domination, control and ability to sanction on the one hand, obedience and discipline on the other hand, does not involve cities in a sustainable urban planning process, but keeps them away" (2003, p. 3I).

The conditions of local political representation and of decision-making structures are fragile. That is why when submitted to act in a formal manner, the trend towards informal networks of power becomes much more pronounced. Coalitions formed by local actors based on common grounds or on differentiated responsibilities and working at different geographical and political scales, constitute an illustration of an informal way of influencing policy options and playing a more important role in urban planning. 
EUE • What urban government for a sustainable urban planning? • c-37

Table I

Demographic and political profiles of elected municipal councils (City councils on the outskirts of Tunis between 1995 and 2005)

\begin{tabular}{|c|c|c|c|c|c|c|}
\hline \multirow{2}{*}{ Function } & \multirow[t]{2}{*}{$\begin{array}{l}\text { Average } \\
\text { age }\end{array}$} & \multicolumn{2}{|c|}{ Gender (\%) } & \multicolumn{2}{|c|}{$\begin{array}{c}\text { Political affiliation } \\
\text { (\%) }\end{array}$} & \multirow[t]{2}{*}{$\begin{array}{c}\text { Turnover rate } \\
(\%)\end{array}$} \\
\hline & & $\mathbf{M}$ & $\mathbf{F}$ & $\begin{array}{l}\text { Ruling } \\
\text { party }\end{array}$ & Opposition & \\
\hline President & 53 & 100 & 0 & 100 & 0 & 50 \\
\hline First assistant & 54 & 100 & 0 & 100 & 0 & 20 \\
\hline Assistant & 50 & 95 & 5 & 100 & 0 & 55 \\
\hline Councillors & 49 & 62 & 38 & 92 & 8 & 70 \\
\hline Municipal councils & 52 & 77,5 & 22,5 & 95,5 & 4,5 & 49 \\
\hline
\end{tabular}

Source: Kahloun, 2008

\section{PRACTICES OF COMPLICITY IN THE FACE OF CONFLICTS OF INTEREST: A NEW ALTERNATIVE FOR SUSTAINABLE URBAN PLANNING}

Local strategies, applied in the process urban planning policy-making and developing infrastructure projects have helped voice and frame the demands introduced in the politico-administrative system in which the local cells of the ruling party play a leading role. It remains no less true that they are chiefly used to establish liaisons with various ruling party actors and maintain good relationships. At the local and regional level, seeking membership in a political party can provide an individual with a unique opportunity to take charge of and formulate social demands. Membership is particularly crucial for mayors or community leaders and political status depends essentially on their arbitration or mediation capabilities.

\section{I Conflicts among different actors and arbitration: informal ways to make the city}

The majority of infrastructure projects become political issues which arise from the grievances by individuals and groups contacted and supported by the local cells. These proposals which are officially defended by the cells and recorded by the omdas (the deputy prefect) are reformulated by the delegate (the prefect) for the region's centre before being submitted to the region's governor in whom is vested all political and administrative power. Central state departments define their infrastructure improvement programmes in cities on the basis of the regional proposals. It follows that local coordination cells are playing a key role in bringing local grievances to the attention of government.

The opening of bank services in Medjez El Bab offers an illustrative example of the importance of local city leaders in advising and directing the demands. In fact, the high proportion of inhabitants of Medjez El Bab who are customers of the Bank of the Habitat $(\mathrm{BH})$ in Béja (the main city of the department), provided the basis for the claim made by the population for a local branch. It should be noted that in 2005, this branch of the $\mathrm{BH}$ was under construction in front of the Medjez El Bab courthouse. At the time, this request, which led to a surge of interest by the local population, was not immediately submitted by the municipal authority to the governor. Due to conflicting relations between the governor and the mayor, the request was conveyed by one of the leaders representing the interests of merchants and contractors of the Tunisian Union of Industry, Trade and Crafts (TUITC). In fact, the leader who served in the role of broker owns several businesses in the city of Argoub Ezzater. In the absence of a genuine local representational body of the TUITC in Medjez El Bab, one of his offices was used to hold meetings and appointments with local and/or regional managers. By 
reaching an agreement through arbitration with the governor, he was able to play the role of a "driving belt” (Dobry, 1992) for local grievances. Through his power of patronage, strengthened by his political allegiance, he was in a position to ensure that his informal power is legitimate and to use his clout more formally to act on behalf of the governor and the local population.

Whether the city is rewarded or penalised depends in practice on the capacity of its local actors to develop, either on a formal or an informal basis, arbitration actions and to channel and transmit local claims and demands. Indeed, forging an alliance between the representatives of local authorities both formally and informally seems to be a determining factor to improve incorporation of grievances into local action plans, bring them to the negotiation table and have them considered by the political authorities at the regional or national levels. We argue that this kind of structure allows some form of complicity through coalitions, and can contribute to the transformation of the political picture of cities and therefore, to the transformation of the urban form.

Within a context of embedded institutional networks, each with their own priorities, local and central government reports pile up on the desks of the delegate, the governor and the local authorities of the ruling party, which seems to block urban development. Indeed, autonomous policy-making by local elected members is impossible since every project proposal or action must first be authorized by the governor. In short, urban development is subject to a consultation procedure with the central authorities at the regional level. More "autonomous" mayors who did not consent in joining local or regional coalitions of interests have seen their proposals blocked by the regional authorities. The refusal to accept regional political decisions dictated by the central state is, in fact, regarded as an obstacle to the process of change and as an attempt to obstruct the state's regional development. Depending on their personalities and the degree of complicity with the party cells, mayors can either get their strategies in place or, on the contrary, fail to rally the population. The mayor of Medjez El Bab provides a telling example. He "attracts investment to take planning action" (interviewed mayor, personal survey, Kahloun, 2008). For instance, not only did the Ministry of Youth and Sports sanction the mayor's proposal to relocate the municipal stadium from a densely-built area, but it accepted to finance the building of a new stadium as well. Although applying for zoning changes would have been the final requirement for this project to move ahead, it was rejected in the end by the governor despite the availability of necessary resources and the benefits of redeveloping the former site for residential purposes. However, the mayor stood his ground and defended his position along with local and regional representatives as the governor faced an impasse. The mayor established an informal network with the central agencies of the state by bypassing the administrative hierarchy under the governor's control. Meanwhile, other initiatives spearheaded by the mayor, such as restoring the facade of the Medjez El Bab Library, or work on redeveloping Arbi Zarrouk Avenue could not have gone ahead without state backing. This has lead to a larger conflict of power sharing. The regional council's position on the powers of the mayor can be summarized as "a malleable dish towel", according to the expression used by the interviewed mayor (personal survey, Kahloun, 2008). The refusal of the mayor of Medjez El Bab to align himself with the network's policy and to be complicit with interest groups prevented him from consolidating his political power base and maintaining it at the regional level. Nonalignment and the rejection of political clientelism would later ruin his chances of reelection.

In the absence of a genuine local urban policy, and to boost their political image, some mayors are looking for new arenas in which to exercise power. For example, increasing the public's engagement in cultural activities is a strategy to gain a political foothold in the city. Only with the continued support of community-based initiatives can the power base include new informal coalitions and provide the conditions for greater autonomy in implementing urban projects. While these projects may not improve the conditions of life for all inhabitants or provide much towards sustainability, such actions at the district level, although limited in scope, are a reflection of a desire to broaden the local power base throughout the city.

Following the example of the strategies to develop infrastructure or to facilitate urban regeneration, the sphere of urban planning appears to be where conflicts between actors give rise to informal networks on which the exercise of authority in cities rests. Indeed, extensions to the urban areas, which are not subject to a framework of negotiation, are frequently proposed without being sufficiently studied and planned in advance. For example, in medium and small cities on the outskirts of Tunis (Mornaguia, Khélidia, Mornague, Medjez El Bab, Borj El Amri, etc.), planners refer to urban development plans (UDP) that are outdated. The urban extension proposals are most likely to be a source of disagreement between local elected representatives 
and the central authorities of the Ministry of Agriculture. Since the 1970s, Medjez El Bab has tolerated the construction of housing estates outside of the authorized urban growth boundary, even though is constitutes a violation of regulations and provisions of the former UDP adopted in 1978. As a result of this breach of law, sprawl and anarchic urbanization has increased considerably at the expense of agricultural land. The urbanized area, which totalled 553 hectares in 1978, has almost doubled to reach nearly 1200 hectares in 2002. Land speculation which spread across the growth boundary established in the UDP is responsible for the proliferation of informal settlements in areas classified as non-urban by the Ministry of Agriculture. Places like El Ajama, El Bahrine, El Azima, El Argoub established over the past fifteen years are illustrations of the tremendous increase in informal settlements in these zones. Given this situation, the municipality sought to integrate these new urbanized zones during the plan review process before submitting it to the Ministry of Agriculture for approval. Although some $80 \%$ of the land is urbanized, central authorities refuse to acknowledge the existence of urban extensions. As a consequence, more than 100 hectares are now located on properties zoned for agricultural use since 1983.

In many respects, it seems that the expansion of cities is not often carried out in a sustainable way since there is no correspondence with the needs for land conversion. The resulting anarchic spatial sprawl, tolerated by local elected officials, reflects a politicoadministrative compromise between the regional development councils and the central state authorities. It follows that the decentralization of local decisionmaking autonomy may counteract the state controlled regulatory framework that underpins the process of urbanization. Indeed, when local and central authorities come together to negotiate a strategy to develop a sustainable urban planning agenda, the resulting structure provides a more appropriate regulatory response to urban growth. Yet, political power, when it is enforced unilaterally in order to come to terms with the emergence and spread of spontaneous urban development and to meet the demands of some segments of the population, facilitates the implementation of non-regulatory approaches to address urbanization and the anarchic spatial sprawl of cities. In spite of this, a number of principles must be followed by authorities when applying predefined models to legitimize sustainable planning guidelines and actions for all cities. These principles of planning include increasing density in existing urban areas, reducing the effects of urban sprawl on agricultural land, providing social housing to promote the inclusion of marginalized groups, supporting the development of a second urban core area, and addressing the problems of traffic congestion and parking problems. They have consequently become key elements for sustainable urban planning, but from this comprehensive perspective, they cannot account for the current state of local environmental resources and correctly address issues relating to infrastructure and employment needs. Therefore, given its limited ability to anticipate and solve problems and the low esteem in which it is held by local elected members and property owners, the development plan is used in many cases merely as a technical management instrument and as a reference document for building and subdividing and not as a legal and regulatory structure. The discrepancy between the overall urban growth trends and local urban planning can be demonstrated by comparing the life-cycle of the urban development plans that should help create a sustainable future for cities and the effective review and follow-up process. In 1978, after 26 years, Medjez El Bab's UDP was finally renewed. Over this period of time, a previously approved plan, partially applied by the local council, was used as a reference to provide standardized solutions to urban development problems.

\subsection{Agenda 21: An attempt at democratizing local planning?}

The purpose of this research is not to examine the sustainable development process in the Tunisian context, but rather to provide insights into the efforts that can be undertaken by local urban governments to create more sustainable cities. Despite the restrictions imposed on local governments in Tunisia, we recognize that the sustainable development process plays an important role in public policy-making. However, the state's sustainability goals are couched in "vague terms" at the local level (Gibbs and Jonas, 2000). Indeed, adapting "Agenda $2 I$ " and "sustainable cities" programmes to the local context becomes more of an issue depending on the degree of decentralization in urban planning.

These programmes are considered as pilot projects that lie outside the regulatory structure used for defining a common set of rules for urban development. They are an expression of the state's determination to regulate urban development, particularly by transferring greater decision-making powers to the local level. In political discourse, a local Agenda $2 I$ is "a first attempt at defining a form of local governance in urban planning". Created under the aegis of the Ministry of the Environment, this initiative, 
despite its limited scope, is founded on the principle of a "sustainable environment" and provides a starting point for future urban development. As Gibbs and Jonas indicate (2000), this process "appears to have been deliberately orchestrated by the central state". By comparing the urban development plan and the local investment programme with other planning tools such as the master plan, we can argue that the local Agenda 21 is entirely disconnected from economic reality and strategies.

The local Agenda 21 is based on the premise of informal coordination between various local and central non institutionalized actors joining in a process that is overseen by the state representatives. This informal attempt to broaden the social base by including representatives of the local government such as the cells of the ruling party, the neighbourhood committees and the community-based associations where they exist, can be seen as part of a wider regulatory framework which is "intended as a showpiece for both the local population and international actors"(Chabbi, 2005, p. I0I). These showpieces serve as a mechanism to "obtain international funds" flowing through agencies that are promoting less rigid cooperation, and to improve the image of the state and thus pay lip service to the idea of serving the interests of cities.

In addition to these attempts to involve local elected representatives and citizens in an urban development project, the state's ability to include environmental concerns in the design and planning of cities is essential to the success of the local Agenda 2l. However, it is not clear whether this is helping increase public authorities' awareness of the need to strengthen local decision-making through the creation of new local structures and negotiation processes. Although in some local Agenda 21 pilot projects, such as Medjez El Bab, the intention of the central government to empower cities and strengthen local governments has not been expressed. With its particular emphasis on the environmental conditions, the project involves local stakeholders in the process which serves to legitimize the state's monopolistic control over urban development. It should be noted that the development of this local Agenda 21 is realized in part through Tunisian and German cooperation. It is supported by funds from the GTZ (Deutsche Gesellschaft für Technische Zusammenarbeit), an international cooperation enterprise based in Germany and active in the area of sustainable development. In support of the Medjez El Bab pilot project, a process was initiated in the year 2000 and enabled a diverse set of local actors and government representatives to come together informally. The local committee which was formed out of the process provided a detailed diagnosis of the city, in collaboration with national and international experts who have received specialized training to implement such initiatives. Together, they set up a development programme in an effort to strengthen the support towards the sustainable development of the city. The work of the Committee 2I of Medjez El Bab resulted in a development programme aimed at safeguarding the environment through urban development, improving economic and social conditions and promoting citizenship.

The results of the experience of the local Agenda $2 \mathrm{I}$ in Medjez El Bab serve as an example to illustrate how engaging the population in a project, despite being a small town with few resources, is essential to success. The Committee 2I was founded not as an institution but as a process through which informal coalitions were created between the elected city and central state representatives who are responsible for environmental protection and land use planning. This kind of working partnership was built on an informal network of managers and citizens involved in various forms of consultation.

Urban development or regeneration actions carried out by this partnership comprising the local elected representatives, the committees of neighbourhoods, the central representatives of the GTZ and the ministry of the Environment, were limited in scope. These actions depended more on the mayor's determination to act locally by drawing on historical and cultural elements to revitalize green and symbolic spaces. This initiative is evidence that urban coalitions can be formed in small towns even when local Agenda projects were unsuccessful in larger cities. Practices of complicity allow abetter understanding of the conflicting pressures that confront small towns in trying to maintain a balance between local demands and national interests. The political and financial dependence on central government remains one of the main barriers to local action. This dominant role of central authorities reduces the ability of local actors to define a sustainable urban planning agenda.

\section{CONCLUSION}

To broaden the debate on the issue of urban governance, we have given more thought to the practice of sustainable urban planning in North African cities developed outside recognized government structures. Faced with the immense fragility of representative and decision-making structures in 
Tunisian cities, both the formal bureaucratic state apparatus and informal networks created by local actors did manage to collaborate to define and implement an urban regulatory plan. In this policy arena, the urban government can operate in "intra or inter-systemic networks" beyond the formal power structure where local action lies outside the control of central authorities. Functioning through these networks of informal or implicit relationships, the system of local power can determine policy positions and decisions at various scales. Advocated by international organizations and prescribed by the central government, development programmes cannot be effectively implemented in cities of the developing world where resource requirements are not fully addressed by an accompanying urban regulatory plan. For this reason, the local Agenda 21 , both in this case study and in general in other Tunisian cities, did not properly reflect the founding principle of "think globally and act locally" or the mode of "thinking in a sectoral way and acting in a central way". The current environment is not conducive to successfully carry out such a programme. The foundations for institutionalized urban governments must first be laid and central authorities must take into account local interests and needs in decision-making.

In addition, if the local Agenda represents for some Tunisian cities a grassroots attempt to build sustainable urban environments and democracy at the local government level, then the results so far are not conclusive. To improve the chances of success, the local power base must play a significant role in decision-making and strengthen their local capacity. The Agenda 21 programme is voluntary and not based on contractual obligations between the state and the local or regional authorities. Rather, it serves as a practical guide to raise awareness about the main problems and issues at stake in urban development, but offers little support for sustainable economic growth and urban planning. Instead, it identifies specific actions for stakeholders that should be followed by local governments.

While some measures were successfully implemented through the Medjez El Bab local Agenda $2 \mathrm{I}$, it did not contribute to solving local urban development problems such as flooding caused by the Wadi Medjerda runoff, the impact of land set-asides on the evolution of agricultural holdings, and the insufficient control of land development and urban sprawl. As a consequence, the project had no direct effect on the sustainability of urban development and urban planning across Tunisian cities. Running alongside other projects, it is a showpiece that enables the state and international agencies to act in an opportunistic way to obtain funds. They harness the potential of local authorities and take advantage of their gullibility to convey an image to international audiences that they were able to conduct a successful experiment in capacity building for local governance and therefore demonstrate the relevance of pursuing sustainable development projects.

\section{BIBLIOGRAPHY}

BOYER, R. et Y. SAILLARD (2002). Théorie de la régulation : l'état des savoirs, Paris, La Découverte, $588 \mathrm{p}$.

CHABBI, M. (2005). Processus d'urbanisation et politiques urbaines dans les pays du sud, le cas de la Tunisie, DHDR en urbanisme et aménagement, Paris, Val-De-Marne, IUP, I52 p.

DE TERSSAC, G. (2003). La théorie de la régulation sociale de Jean-Daniel Reynauld - Débats et prolongements, Paris, La Découverte, $448 \mathrm{p}$.

DEGENNE, A. et M. FORSE (1994). Les réseaux sociaux. Une analyse structurale en sociologie, Paris, Armand Colin, 284 P.

DOBRY, M. (1992). Sociologie des crises politiques, Paris, Presse de la Fondation Nationale des sciences politiques, $319 \mathrm{p}$.

GAUDIN, J.-P. (2002). Pourquoi la gouvernance?, Paris, Presse des Sciences Politiques, $137 \mathrm{p}$.

GAUDIN, J.-P. et G. NOVARINA (1997). Politiques publiques et négociation : multipolarités, flexibilité, hiérarchie, Paris, CNRS, $167 \mathrm{p}$.

GIBBS, D. and A.E.G. JONAS (2000), "Governance and regulation in local environmental policy: the utility of a regime approach", Geoforum, n³1, p 299-313.

GODARD, F. (1997). Le gouvernement des villes, territoire et pouvoir, Paris, Descartes, 287 p.

KAHLOUN, H. (2008). Les processus d'urbanisation des petites villes à la grande périphérie de Tunis, Thèse de doctorat en urbanisme et aménagement. Tunis-ENAUT, $446 \mathrm{p}$.

LE GALÈS, P. (1998). "Regulations and governance in European cities", International Journal of Urban and Regional Research, vol. 22, n³, p. 482-506.

LE GALÈS, P. (2003). Le retour des villes européennes, sociétés urbaines, mondialisation, gouvernement et gouvernance, Paris, PFN Sciences politiques, 454 p.

LEMIEUX, V. (1976). "L'articulation des réseaux sociaux », Recherches Sociographiques, vol 17, $n^{\circ} 2$, Québec, Université Laval, p. 247-260.

LEMIEUX, V. (1977). «Réseaux et appareils dans l'implantation de deux C.L.S.C. », Recherches Sociographiques, vol $17, \mathrm{n}^{\circ} 2$, Université Laval, p. I77190. 


\section{EUE • What urban government for a sustainable urban planning? • c-42}

LEMIEUX, V. (I99I), «Réseaux et appareils. Logique des systèmes et langage des graphes » in de ROGER, T. et T. YVAN (Ed.), Théories de l'organisation. Personnes, groupes, systèmes et environnement, Québec, Les Presses de l'Université du Québec, p. 209-230.

LEMIEUX, V. (1997). «Réseaux et coalitions », L'Année sociologique, vol 47, $n^{\circ}$ I, Paris, PUF, p. 35I-370.

SOUAMI, T. (1998). «Participer à la gouvernance », Les Annales de la Recherche Urbaine, ${ }^{\circ} 80-81$, p. 163-17I.

STONE, C.N. (1989). Regime Politics: Governing Atlanta, 19461988, University of Kansas Press, Lawrence, KS.

STONE, C.N. (1993). "Urban regimes and the capacity to govern: a political economy approach", Journal of Urban Affairs, $n^{\circ} 15$, p. I-28. 